\title{
NOTES ON THE GREEK FOOT RACE.
}

\section{I.-The Arrangements of the Stadium.}

THE recent discoveries at Olympia, Epidaurus, and Delphi have forced us to modify the old idea of the Greek race course based on the stadium of Athens and the Roman circus. It may perhaps be useful shortly to state the evidence which we now possess.

\section{A.-The Homeric Race Course.}

Running is the most universal, the oldest of all forms of sport, and the primitive form of a race is that which the competitors run from one point to another-the germ of the stadium or straight race-or where they race round some distant object and back to the starting place-the germ of the diaulos and other turning races, as the Greeks call them (ка́ $\mu \pi \epsilon \iota \iota)$. This simple type of race, which we may see to-day at school treats and rustic meetings, requires no apparatus but two posts, stones, or other objects to mark the starting point, and the finish, or turning point; and it is this primitive type that we find in Homer. In the twenty-third Iliad ${ }^{1}$ Achilles places the

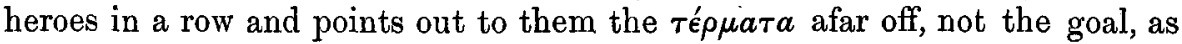
we can see by comparing the similar expressions used of the chariot race, but the turning point. In the chariot race this was a withered stump a fathom's height above the ground, with two white stones set on either side, and by it Achilles set an umpire, godlike Phoenix, "that he might note the running and tell the truth thereof.' Just such a figure appears in later times on vases $^{2}$ standing with his forked rod beside the turning point ready to chastise any offence or breach of the regulations. The starting point in Homer is called $\nu v ́ \sigma \sigma a$, a word generally used of the turning point, but signifying merely a 'meta' or post, and so equally applicable to either end.

\section{B.-The Hixpodrome type of Race Course.}

From this primitive type two types of race course are derived. The first we may call the Hippodrome type, where as in Homeric days the horses or men race round two posts, connected by one or more intermediate posts, or 
by a low wall like the 'spina' of the Roman circus. This type of course was not confined to horse racing, and though generally superseded in foot races by the more elaborate arrangements which we find at Olympia and elsewhere, it reappears in later times when the glory of the foot race has already declined with the growth of professionalism and luxury. Thus the stadium at Athens first built by Lycurgus in the 4th century B.c. and magnificently rebuilt by Herodes Atticus in the 2nd century of our era was divided by a low wall running down the middle and connecting three pillars, one of which, a square pillar with the heads of Hermes and Apollo set back to back, is in the museum at Athens. A similar arrangement is described by a scholiast to Soph. Electra 691, who mentions three square pillars bearing on

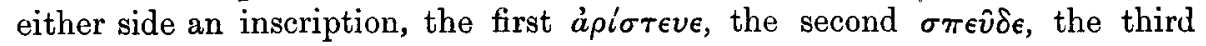

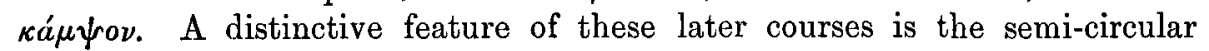
theatre or $\sigma \phi \epsilon \nu \delta \delta^{\prime} \eta \eta$ at one end or, as in the Roman circus, at both ends. This circular ending, which doubtless served for various gymnastic or other contests, does not belong to the earlier type of course which we- find at Olympia, and in the case of Delphi it seems to have been a later addition. $^{\mathbf{3}}$ In a course of this description the runners were not separated in any way from one another and opportunities for foul play must have been frequent, especially at the turn. That such foul play did occur is proved by the regulations against tripping or otherwise interfering with an opponent. ${ }^{4}$ According to a tradition preserved by Statius ${ }^{5}$ such an incident occurred at the founding of the Nemean games, when Idas seized Parthenopaeus by the hair and so prevented him from winning. Adrastus directed that they should run the race again and that to prevent a repetition of such tactics they should run on opposite sides of the course. Again, Vergil ${ }^{6}$ represents Nisus as purposely tripping Salius. These practices if they belonged to Greek times at all must have been confined to the type of race course described, or to races run in the same way.

\section{C.-The Starting Arrangements. The $\ddot{\sigma} \sigma \pi \lambda \eta \xi$.}

Of the method of starting on such a course we cannot speak with certainty. The two primitive methods of starting are by means of a line drawn in the sand, ${ }^{7}$ or by a rope placed in front of the competitors, which is dropped at the moment of starting. This latter method was undoubtedly employed in the chariot races. At Olympia the chariots were arranged in pairs along the sides of an isosceles triangle, the apex of which pointed to the right of the first 'meta.' 8 At a given signal the ropes or $\ddot{v} \sigma \pi \lambda \eta \gamma \in$ in

3 For the stadium at Athens $v$. Frazer, Pausanias î. 205 ; at Olympia $v$. Olympia ii. 63 and Frazer, iv. 78; at Delphi, B.C.H., $1899, \mathrm{pp} .601-615$; at Epidaurus v. Frazer, v. 576.

4 Luc. cal. non tem. cred. \$12; Paus. v. 24.2. . v. Krause, Gymnastik der Hellenen, p. 363,

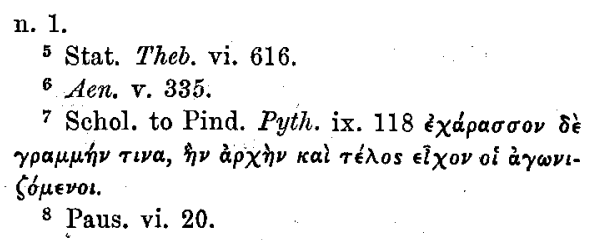

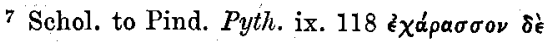

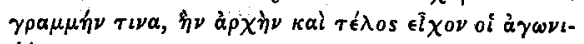

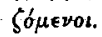

8 Paus. vi. 20. 
front of the pair nearest the base were dropped; as this pair drew level with the next pair the next ropes fell, and so on until the whole field were fairly started. The plural $\ddot{v} \sigma \pi \lambda \eta \gamma \in s$ therefore came to denote 'the starting place,' and the phrase $\ddot{\omega} \sigma \pi \epsilon \rho$ àmò $\mu \iota \hat{s} s \dot{v} \sigma \pi \lambda a \gamma i \delta o{ }^{9}$ is used proverbially in Aristophanes to describe a simultaneous start. It is difficult to decide how far the use of this term as applied to the foot race is metaphorical, how far it is based on fact. In the epigram written by Antipater on the celebrated Ladas

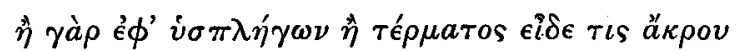

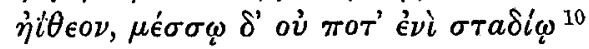

the word may be used metaphorically. But the use of a rope in starting is distinctly implied in the somewhat obscure words of Lycophron

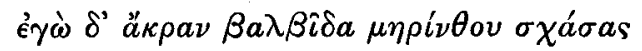

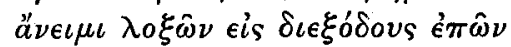

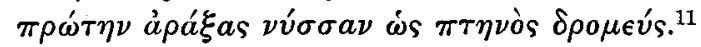

And a much later writer Heliodorus in his fanciful description of an armed race describes the start by the words

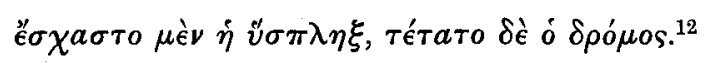

More convincing evidence is afforded by an inscription published in the 'E $\phi$. 'A $\rho \chi .1884,169$, referring apparently to repairs of the stadium, in which occur the words

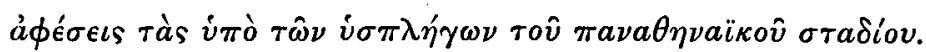

From these words and from the expression of Lucian $\epsilon \pi \epsilon \sigma \epsilon \nu$ i $\nu^{\prime} \sigma \pi \lambda \eta \xi$, $^{13}$ we may infer that the rope was raised some height above the ground; from the use of the word $\sigma \chi a \dot{\zeta} \epsilon l v$, which denotes opening or slitting something tight like a vein or a haggis, we may conclude that the rope was stretched tight. Moreover it must have been dropped or let go very suddenly and pulled away quickly to avoid entangling the runners' feet, and this sudden loosening of the tight rope was accompanied by an audible sound which is referred to in the epigram on Pericles. ${ }^{14}$

Dr. Hauser ${ }^{15}$ has tried to identify the $\boldsymbol{v} \sigma \pi \lambda \eta \xi$ on two vases, a Bourguignon skyphos which I shall discuss later, ${ }^{16}$ and a kylix in his own collection. But M. de Ridder ${ }^{17}$ has pointed out that in the former the supposed line is too indefinite to be of any value, and even if it is a rope, it is resting on the ground; while on Dr. Hauser's kylix the line which passes through the hoplite's right hand may with more probability be regarded as a spear : for the identical position occurs on a Pamphaeus kylix in the Louvre (G. 5),

${ }^{9}$ Aristophanes Lysistr.' 1000.

10 Anth. Pal. ix. 557.

11 Lycophron 13.

12 Aeth. iv. $3 \mathrm{f}$.

$1 s$ Lucian, Tim. 20.

14 Anth. Pal. xi. 86

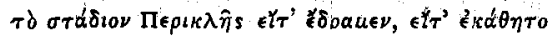

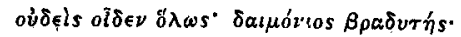

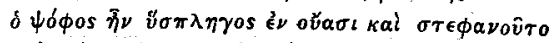

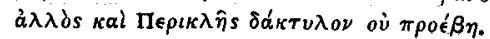

.15 Jahrb. 1895, p. 193.

16 P. 28\%, Fig. 10.

17 B.e.H. 1897, p. 233. 
where there can be no doubt that the object is a spear. The proposed identification must therefore be regarded as a failure.

It appears then from the evidence that a rope was sometimes used for the start of the foot race. This practice was probably borrowed from the Hippodrome, and at a late date when the importance of the foot race was decreasing. A starting rope would be superfluous with the elaborate starting arrangements of Olympia; indeed there is direct evidence that it cannot have been used. With a rope, just as with the starting gate which has been introduced of late years in the horse race, there is no possibility of poaching. at the start or of a false start. Yet such incidents were quite familiar to the Greeks. In the council before Salamis Adeimantus says to Themistocles,

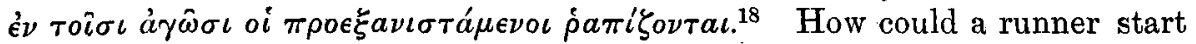
too soon if kept back by a rope? Again in Aristophanes, Equites the sausage seller protests against Cleon's trying to steal a march on him, $i \pi \circ \theta \varepsilon \hat{\imath} \nu$ ov $\dot{\epsilon}^{\prime} \hat{\omega}^{19}$ - no poaching at the start. How could he start before him if they were both kept back by a rope? In later times Plutarch describes the

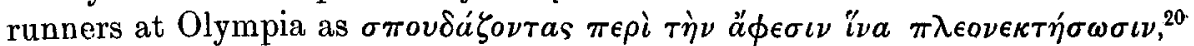
and Julian implies that those who started too soon were called back to the start. ${ }^{21}$ Such passages are incompatible with the use of the $\ddot{v} \sigma \pi \lambda \eta \xi$ and when we set beside them the constant allusions in writers of the 5 th century to the $\gamma \rho a \mu \mu \eta$ or starting line ${ }^{22}$ we are led to the conclusion that the use of the $\ddot{v} \sigma \pi \lambda \eta \xi$ in the foot race was a late invention, and even then never became universal and was only used in the Hippodrome type of course with its $\nu$ v́ $\sigma a \iota$ or its spina, and not in the type with which recent discoveries have made us familiar.

\section{D.-The Stadium of Olympia.}

This second type is fitted only for foot races. There are no posts nor wall down the centre of the course, which is a long rectangle, terminated at either end by a row of stone slabs. At Olympia these slabs are $4 \mathrm{ft} .2 \mathrm{in}$. long and $1 \mathrm{ft}$. 6 in. broad, divided from one another by square sockets, obviously intended to hold posts. There are twenty of these slabs at either end at Olympia and each slab is marked longitudinally by two parallel grooves about seven inches apart. Similar slabs have been found too in the Gymnasium to the west of the altis. These grooves were clearly meant to mark the position of the runners' feet, not so much in order to give a firm grip for the toes, much less for the heels as has been asserted,-for a slight. roughening of the stone would have been far more effectual,-—but rather by defining the position of each foot to ensure a fair start. At Delphi we find a similar arrangement; but the lines on the slabs, of which there were probably seventeen, are nearer to each other, only $3 \frac{1}{2}$ inches apart. At Epi-

\footnotetext{
18 Hdt. viii. 59.

19 Eq. 1162.

20 Plutarch, Apophth. Lac. (Leont. fil. Euryer.

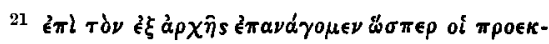

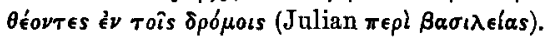
§).

${ }_{22} \gamma \rho a \mu \mu$, Aristoph. Acharn. 481. Eurip. El. 955. Frag. 169. Pindar, Pyth. ix. 118.
} 
daurus the lines are about 4 inches apart, but the stone sill only occurs at one end of the race course and there are only eleven pairs of lines. It seems probable that there was originally a second stone sill $a^{+}$Epidaurus also, but all trace of this has disappeared owing to the shallowness of the soil. The object of having a stone sill at both ends was to enable all the races, whether over the single or double course, to finish at the same point. On a course with only a single sill, if there were any such, the winning post for the stadium must have been at the opposite end to that for the other races. In front of the stone sill at Epidaurus are seven stone pillars which seem to be remains of a later arrangement for starting, perhaps resembling the Roman carceres. A relief published in the höm. Mitth. 1890, p. 156, Taf. 7, representing runners apparently about to take their place behind a wooden barrier, perhaps shows us such an arrangement, but it is probably connected with the Roman circus rather than with the Greek stadium, and in the present state of our knowledge we can say nothing definite of these later arrangements at Epidaurus.

In these stone slabs we have the $\beta a \lambda \beta i \delta \delta$ er thresholds, a word which Philostratus uses in the singular to express the platform on which the diskobolos stood, ${ }^{23}$ and we can now understand why this word like $\tilde{v} \sigma \pi \lambda \eta \xi$ is

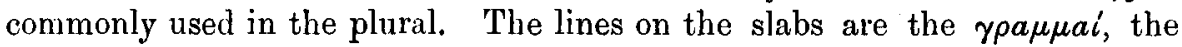
development of the line which, according to the scholiast to Pindar, ${ }^{24}$ men used to dig to mark the start and finish. A passage in Eustathius

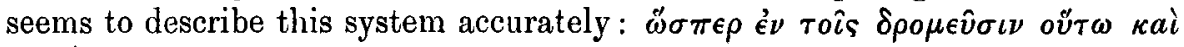

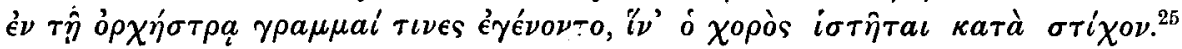
In a most interesting inscription discovered at Delphi and published in the

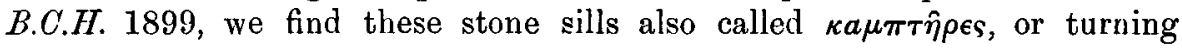
points, a word which properly describes the posts which separated the

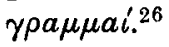

This inscription contains details of expenses incurred in the archonship of Dion (B.c. 268) in preparing for the Pythian festival. First the ground, which had possibly been used as pasture land, had to be thoroughly cleared. This $\dot{\epsilon} \kappa \kappa a \theta a \rho \sigma \iota s$ cost 15 staters. Then it was dug up and rolled, the $\sigma \kappa a \psi$ is $\kappa a i \delta \mu a ́ \lambda \iota \xi \iota s$ costing a further sum of 110 staters. Six $\dot{\pi} \pi \iota \sigma \kappa a \phi \epsilon \hat{\imath} a$ or picks for harrowing were provided for digging the stadium and the jumping places or ä $\lambda \mu a \tau a$. Finally the course was covered with a layer of white sand, 600 medimnoi being provided at a cost of $1 \frac{3}{4}$ obols per medimnos. This inscription should finally dispose of the fiction that the Greeks ran races in deep sand. From Lucian's ${ }^{27}$ Anacharsis we learn that they practised running in sand as a severe form of training, but this does not prove that they raced under such conditions at the great festivals, any more than Aristotle's remark ${ }^{28}$

23 Phil. Imag. i. 24.

24 Pyth. ix. 118.

Eustathius, $I l$. ix. p. $7 \% 2.9$.

26 The sum of 36 staters was spent on the

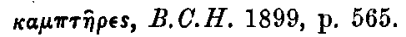

H.S.-VOI. XXIII.
27 Lucian, Anacharsis, 27.

28 Arist. De Gressu Anim. p. 709. olov \&

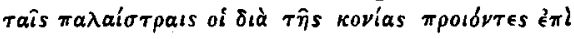

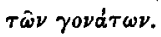


about running on their knees in the Palaestra proves that they raced on their knees.

One more point remains. What was the use of the square sockets between the slabs? They were evidently meant for pillars, and it has been suggested that the course was roped as it is in the present day for the Hundred,Yards Race. For this suggestion there is, I believe, no direct evidence, but_we can understand how necessary it would be for every runner to have some definite point for which to run. Without such a point it would be very difficult to run straight in a broad track like that of Olympia, and we may therefore assume that even if the course were not.roped the various posts were distinguished in some way or other so that each runner would run straight for the post opposite him, and that probably the line was marked in

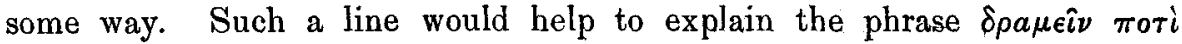
$\sigma \tau a ́ \theta \mu a \nu$ (Pind. Nem. vi. 7). Prof. Bury states that $\sigma \tau a ́ \theta \mu \eta$ in Pindar never means 'a goal' but rather 'a measure or rule' and the phrase means 'to keep to one's course.' The word might well denote the line, however marked, which connected the starting post with the post opposite it, the line to which each runner had to keep.

\section{E.-Heats.}

The arrangements at Olympia probably represent the usual arrangements of the course, at all events at the great festivals. $A$ few words must be said about the question of heats ( $\tau a^{\prime} \xi \in \iota \varsigma$ ). Our only information on this point is derived from Pausanias vi. 13. 2. The text of the passage is corrupt, but it appears that in the stadium race the competitors were divided into heats of four, the winners of which ran in the final, so that the winner had won twice, once in his heat and once in the final. This seems conclusive with regard to the stadium race. The race was the most important of all the athletic contests. The winner of the stadium race gave his name to the Olympiad, and in an Athenian inscription which enumerates the prizes for the Panathenaic"'festival ${ }^{29}$ the winner of the stadium race receives ten amphorae more than the winner of any other event. It was natural therefore that particular pains should be taken with the arrangements for this race, but it does not follow that the same system was applied to the diaulos or even to the stadium race in the Pentathlon. In the latter it would have been undesirable to lengthen the competition by heats unless absolutely necessary, and the starting lines at Olympia allowed room for twenty to start together. In the diaulos possibly only half that number could have run; but it does not seem likely that the entries were large. The thirty days' training at Olympia must surely have led to the weeding out of those who had no chance. At all events we may feel certain that in such a trying distance as 400 yards heats would have been avoided if possible. Else the triple victor who, having won two or more heats in the diaulos and two or more in the stadium, proceeded on the same day to win the long race, would 
have been indeed a marvel. From the obscure and corrupt passage in Sophocles Electra, 691-2, it is impossible to argue. If heats were unlikely in the diaulos they were much more unlikely in the long race, the distance of which is variously given as $7,10,12,20,24$ stades. $^{30}$ The origin of this divergence is undoubtedly due to the fact that the distance varied at different festivals and at different times, just as in the present day. For Olympia the evidence is slightly in favour of a 24, stades race. But whether the race was one mile or three, there can have been nothing to prevent large numbers running together for such a distance, and heats would have been as tedious to the spectators as trying to the competitors. An epigram on one Charmos ${ }^{31}$ mentions 7 men running in the long race, and suggests a possibility of twelve running together. According to another epigram ${ }^{32}$ Hermogenes of Antioch beat nine competitors in a race. Such passages are sufficient to refute the idea that the Greeks always raced in heats of four. ${ }^{33}$

\section{F.-The manner of running the various races.}

The next point to be considered is the manner of conducting the various races. The stadium race offers no difficulty : each runner ran straight to the post opposite his starting point. The question of the diaulos is more difficult. The centre socket in one of the lines at Olympia is larger than the others and Dr. Dörpfeld is of opinion that in the diaulos the other posts were all removed and only the central one was left, round which all the competitors raced. 'This theory is open to two objections. Those who started on the outside would have further to run than those who started in the centre. This inequality, amounting at the most to a yard, is not a really serious consideration in a race of 400 yards. It becomes more serious however when we consider the nature of the turn. In a race of this distance the runners would not be much separated in the first two hundred yards, and much confusion and crowding would result in turning sharply round the post. Everything would depend on reaching the halfway post first in order to avoid the confusion and delay in making the turn. Hence the loss or gain of a yard at the start might cause the best runner to be crowded out at the turn, and enable an inferior one to turn without trouble. Accordingly Flasch, Hauser, and others maintain with some plausibility that in the double race each man ran not to the central post but to his own post and then turned. At the same time we must remember that such crowding at the turn was allowed in the chariot race and it is impossible without further evidence to determine the point. But supposing that the separate posts

\footnotetext{
${ }^{30}$ Krause, Gymnastik der Hellenen, p. 348.

31 Anth. Pal. xi. 82.

32 Anth. Pal. vi. 259

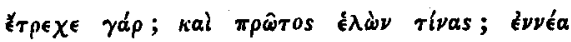
maîsas.

${ }^{33}$ Mahaffy, Rambles and Slacties in Greece, 3

p. 310. Mahaffy speaks of an $\epsilon_{\phi \in \delta \rho o s}$ but I
}

can find no proof of the existence of a bye in the races, though proofs are frequent of a bye in wrestling and boxing. The analogy of the chariot race where we hear of ten chariots racing together (Soph. Electra) is an additional argument against the genersl use of heats. 
were used, how did they turn? Did they touch the post or toe the line and turn back along the same course by which they had come? Or did they turn to the left round the post to the left and return along a parallel course? The evidence seems to me sligbtly in favour of the latter view. The name 'diaulos' signifying a double channel seems in favour of it; so too is the

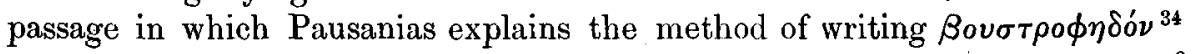
by comparing it to the diaulos, or again the line in the Agamemnon of Aeschylus 343,

\section{$\kappa a ́ \mu \psi a \iota ~ \delta \iota a v ́ \lambda o v \theta a ́ t \epsilon \rho o \nu \kappa \hat{\omega} \lambda_{o \nu} \pi a ́ \lambda \iota \nu$.}

The analogy of the chariot race and the Homeric race supports this view, and the use of the words $\kappa a \mu \pi \tau \eta^{\prime} \rho$ and $\nu v \sigma \sigma a$, which Pollux defines as that point $\pi \epsilon p i$ o $\kappa a ́ n \pi \tau o v \sigma \iota$, though these words may refer to the Hippodrome or to the type of stadium which resembled it. Possibly a further confirmation of this view may be found in the vase paintings which I propose to discuss in connection with the armed race, though in this case it seems to me certain that the competitors raced round one common point and not round separate posts. But whatever was the case in the diaulos there can be no doubt that in the long race all competitors raced round the central posts at either end. In a long race the runners soon spread out; the pace is less and the difficulty of the turn is minimised. Moreover the system by which each man keeps to his own track, though convenient in a short race, is actually inconvenient in a long race when each lap has to be registered and each turn watched by the officials, and the runners themselves would find it difficult to know how they stood with regard to their fellow competitors. A Panathenaic amphora published in Mon. d. I. i. 22 actually shows four long distance runners running to the left towards a rough post. The foremost runner has just reached the post, his left foot just passing it. but he has not yet turned. The post of course might represent the finish, but the style of the running is opposed to this. To sum up: the separate posts were certainly used in the stadium race, possibly in the diaulos, but certainly not in the long race, which was run in the same way as the chariot race.

\section{II.-The Evidence of Vase Paintings.}

\section{A.-Style of Running.}

So far vase paintings have been of little use in our enquiry: but when we come to the style of the running and especially to the conduct of the armed race, vases are our chief authority. The difference of style between the Stadiodromos and the Dolichodromos as we see them on the Panathenaic vases is familiar to every one. Of the long distance runners I need say only that they are a model of style for all time ${ }^{35}$; but the style of the sprinter as he advances by a series of leaps and bounds swinging his arms like the sails 
of a windmill ${ }^{36}$ is apt to provoke a hasty smile. ${ }^{37}$ Hasty, I say, because it neglects to take account of the extreme difficulty of depicting a sprinter, and of the character of the vases on which we see him. These are for the most part Panathenaic vases, prize vases which contained the oil given to the victors. The artists were limited to certain set subjects treated, as is natural with vases thus produced, usually in a conventional way, and not always drawn with great care. Many of those which have been preserved to us are archaic, many more are archaistic, and at first sight the archaic is always apt to produce a smile. But if we make allowance for these facts, instead of laughing we shall rather wonder at the truthfulness with which, in spite of a sometimes grotesque exaggeration, the artists have really depicted the essential points of a sprinter, running on the toes, raising the knees, and using the arms. Homer is true to nature when he tells how Odysseus, as he neared the finish, prayed to Athene and she made him light both of hands and feet. ${ }^{38}$ So Philostratus says that the Stadiodromoi use their arms to

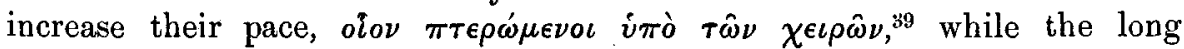
distance runners only do so at the end of the race, i.e. in their sprint. In the present day nearly all sprinters make use of their arms, though the exaggerated use is not recommended; one well-known sprinter is described in the Badminton Athletics as a vision of whirling arms and legs. One has only to compare the Stadiodromoi on a Panathenaic vase with an instantaneous photograph of a hundred yards race to realise that in spite of stiffness and conventionality the Greek artist was not far from the truth. The action of the armed runners is, as we should expect, more violent than that of the long distance runner, less violent than that of the sprinter. M. A. de Ridder in a paper to which I shall have to refer at length ${ }^{40}$ wrongly describes the Hoplitodromos as advancing by a series of leaps and bounds. The two examples figured in the Mon.d. Inst. x. 48. e. 3 and g. 9 are sufficient to refute this; the first, an amphora now in the British Museum, ${ }^{41}$ dated 336 B.c., shows four runners making a very moderate use of the arms and running on a perfectly flat foot; the second amphora, now in the Louvre, belonging to the year 323 B.c., shows three runners running on the toes, but with the right arm close in to the side as we see it in the long distance runners. The obvious inference is that the style of the armed runner comes between the styles of the sprinter and of the long distance runner.

\section{B.-The attitude of the Start.}

In connection with the armed race a number of questions have been raised by Dr. Hauser in the Jahrbuch for 1887 and 1895. In these articles Dr. Hauser tries to determine from vase paintings

\footnotetext{
${ }^{36}$ Mon.d. I. x. 48. f. 7, Gerh. A. V. 259 ; cf. a very beautiful representation of winged run38 Il. xxiii. 772. ners published by Miss Hutton B.C.H. 1899 , p. ' 159.

39 Phil. Gymn. 32.

4) B.C.H. 1897, p. 222.

${ }^{37}$ Mahaffy, Rambles and Studies, ${ }^{\circ}$ p. 308.
} 
(1) the position of the start,

(2) the manner of the turn in the diaulos

(3) the length and general arrangement of the armed race.

His conclusions have been assailed by M. A. de Ridder in the B.C.H. for 1897. Both writers appear to me to prove too much, and as $I$ am unable to agree with either of them, I will venture to suggest a third view which is really a compromise between the two.

First, as to the position at the start. In the Tübingen bronze statuette,.2 formerly described as a charioteer, Dr. Hauser believed that he recognised an armed runner whose shield had been broken off', and after much hesitation he decided that he was a runner ready to start. The bronze represents a bearded athlete with the right foot a few inches behind the left foot, almost level with the instep. Both kuees are slightly bent, the body leans slightly forward; the left arm which once carried the shield is bent and drawn somewhat back, while the right arm is extended to the front slightly below the level of the shoulder. The whole attitude is that of a man at rest, but on the alert and expectant, ready for immediate action. Closely parallel to this figure is a red figured amphora from Naples, now in the Louvre ${ }_{2}^{43}$, showing

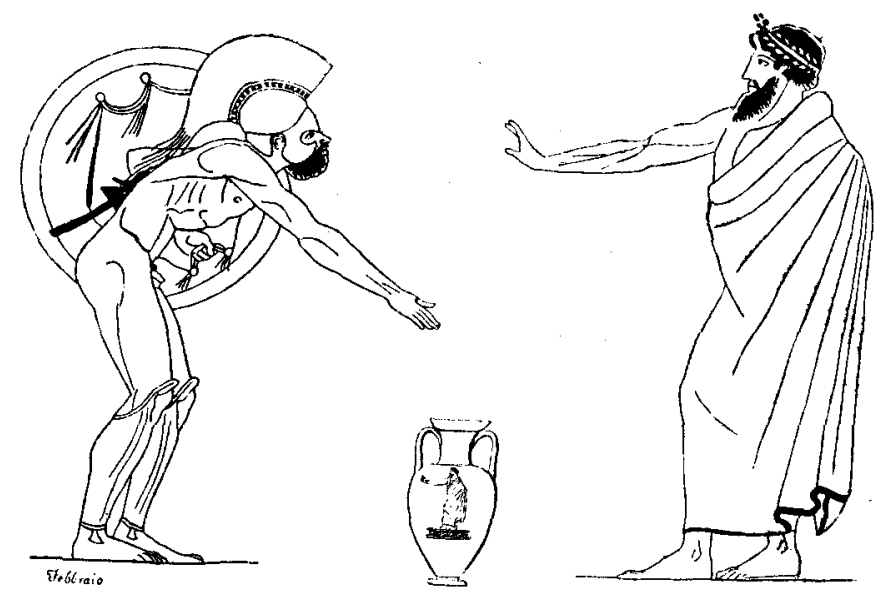

Fig. 1.-R. F. AMpiora IN THE: Louvie.

an armed runner in an almost identical position but with the body stooping forward a trifle more (Fig. 1). Opposite him is a draped figure with the right arm extended to the front and the hand bent backwards and upwards, an attitude which according to Dr. Hauser signifies 'Halt!' It is precisely the gesture of a photographer as he says 'keep still please,' and is most appropriate to a 
steward starting a race. Still closer to the Tuibingen bronze is the figure on a Leyden kylix ${ }^{44}$ but in this case the official is replaced by a pillar which stands in front of the right arm of the athlete. It might well be one of the pillars at either end of the stone sill which we have found marking the start at Olympia. The same attitude recurs on a Berlin kylix ${ }^{45}$ which represents the whole course of the armed race (Fig. 6). The right-hand figure of the three, whom I take to be on the point of starting, only differs from the previous figures in that the right foot is to the front, and the left heel is accurately represented as raised slightly off the ground with the result that the left knee is somewhat more bent than the right. The body too is bent more forward, in which respect it resembles an unarmed runner on a vase figured by Krause xv. $55,{ }^{46}$ which seems to me beyond all doubt to represent an

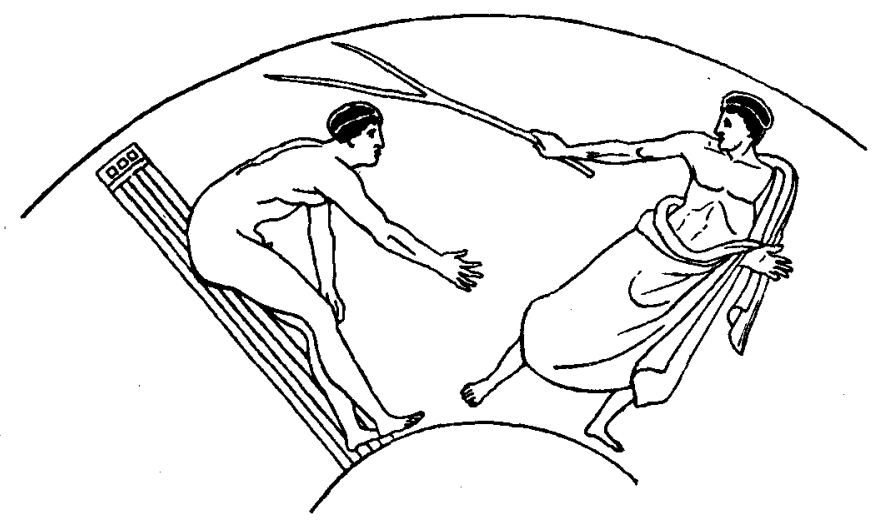

Fig. 2.-R. F. Kriti, Formeris at Naples. (After Dubois-Maisonnenve).

athlete practising starts in the Palaestra (Fig. 2). The athlete stands beside the pillar, the right foot foremost, the left heel slightly raised. $\mathrm{He}$ bends forward, his body almost horizontal, the right hand extended to the front and towards the ground, while the left arm is carried somewhat backwards for the sake of balance. A draped figure carrying a forked staff seems about to give the word to start. Lastly in a vase figured by Hartwig ${ }^{47}$ we see another unarmed athlete standing by a pillar in the precise position of the Tubingen bronze, except that as he las no shield to inconvenience him both hands are stretched to the front. Perluaps we may add to these the statue of the Victorious Running Girl in the Vatican, but the identification of this with the start is very doubtful.

There can be no doubt that the motive in all these figures is the same,

4t Jahrbuch, 1887, p. 99.

45 Ger. $A . V .271$.

45 The vase is figured in Dubois. Maisonneuve. Taf. xxv. and Inghirami, Mon. Etrusc. v. 2. Taf. Ixx. It was at Naples, but I lave failed to discover where it is now. This is the more to be regretted 'as the differences between the two drawings show that they cannot be accurately drawn.

47 Meisterschalen, p. 45, f. $\dot{6}$; cf. a similar figure on a vase belonging to $\mathrm{Si} \mathrm{r} F$.

described below p. 288. 
but do they represent the start? The most important point in which they all agree is the position of the feet; a point which is to my mind conclusive, inasmuch as it corresponds accurately with the position required by the two lines on the slabs which mark the start at Olympia, Epidaurus, and Delphi. These lines are from 4 to 7 inches apart, and the hind foot on all the vases I have mentioned and in the Tuibingen bronze is level with the heel or instep of the front foot. This position of the feet is decidedly unusual and determines the whole attitude of the body; and the agreement between the starting lines and this position of the feet is the very strongest proof that the moment represented is that of the start. Unfortunately Dr. Hauser, not appreciating the importance of this point, confines his attention to the bend of the knees, and extension of the hands to the front. This neglect of the position of the feet has led him to assign to the same motive vases representing several distinct motives. With the vases which $\mathrm{I}$ have mentioned as really showing the start, he compares a number of vases showing two types not of running, but of jumping. In one type the feet are absolutely parallel, the legs together, and the knees very much bent, while both hands are swung to the front (Figs. 3 and 4). In one of these vases the performer is actually standing on a raised

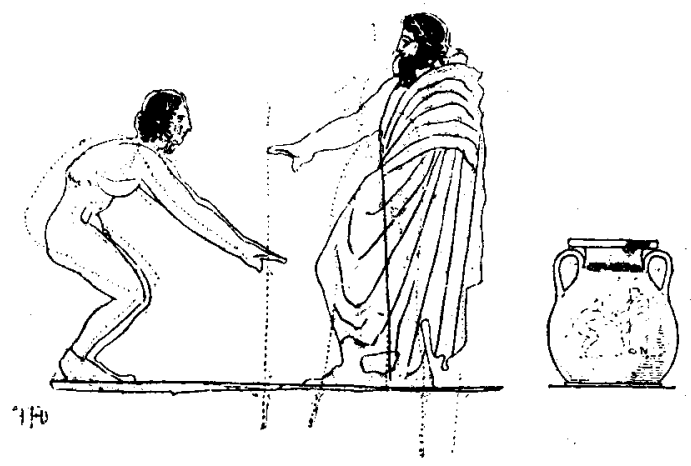

Fig. 3.-Pelike belonging to Dr. Hauser.

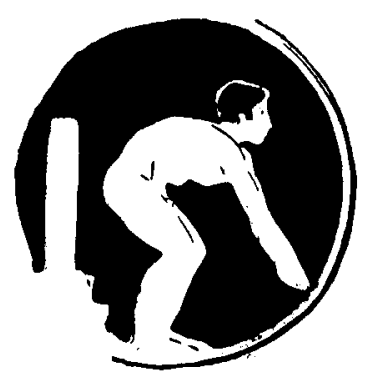

FIG 4.-R. F. KYLIX, MUNICH.

Athletes Jumping without Halteres.

stand $(\beta a \tau \eta \dot{\eta} \rho) .^{48}$ In the other type the legs are more or less separated, the hind leg alone is bent, and the position represented is almost identical with that of the jumper on the Berlin or British Museum bronze diskos. ${ }^{49}$ Both series are extremely interesting as showing undoubted types of jumping without weights, but the discussion of them comes under the heading of jumping, not of running. Other vases are grouped under the sime head by Dr. Hauser because he has failed to consider the general intention of the painter. For example in the black figured oinochoe in the British Museum ${ }^{50}$ showing a

48 Hancarville, Ant. étr. gr. ct rom. T. iii. 66. Krause ix. 23, Hauser, Jahrbuch, 1887, p. 106. ef. Jahrbuch, 1895, Figs. 3, 4 in Hauser's article, and B.M. E. 101.

49 Jahrbuch, 1895, loc. cit. Figs. 7, 8, 9, 10.

50 B.M. Vases B. 628. 
Hoplitodromos standing in a statuesque attitude upon a raised bema, the obvious intention of the artist is to represent not a living athlete but a statue. This is shown by the stiff attitude of the Hoplitodromos, the gesture of the priest or worsbipper who stands before the figure, and the presence of the pedestal. Or again to take another vase in the British Museum, ${ }^{51}$ the long thin athlete who.is stretching out his hand with a mocking gesture must not be separated from the short, fat-bellied boxer opposite to him (Fig. 5 ). The motive

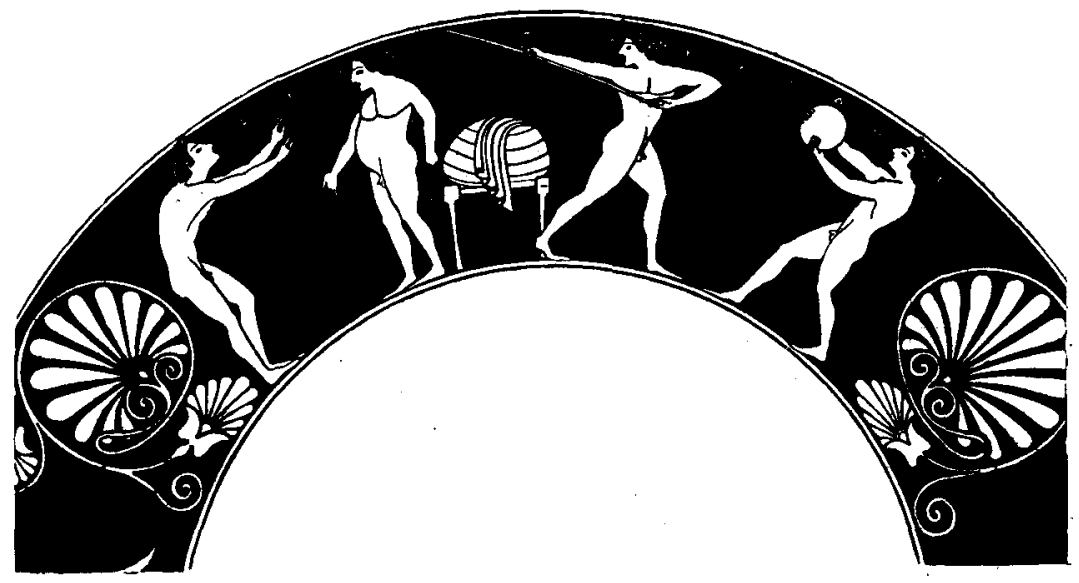

Fig. 5.-R. F. Kylix in B.M.

is, as $\mathrm{Mr}$. Cecil Smith explains, obviously humorous, and represents some altercation between the two. ${ }^{52}$ Perhaps the fat boxer has challenged the other to decide the dispute with the gloves! One feels tempted to ask whether the artist may not be caricaturing some characters of his own time. But Dr. Hauser does not seem to realise that Greek athletics and the Greek palaestra had a lighter side, that Greek life was full of humour, and much study had not blinded the Greek artist to the appreciation of humour. Again, apart from the context of the figure, its position has but a superficial resemblance to the series which represent the start. The position of the feet is not the same, they are all but parallel. But let that pass. In the Tiubingen bronze and the figures resembling it, the body rests chiefly on the front leg, or on both evenly, and both knees are bent. Here the weight of the body is on the back leg, the knee of which is absolutely straight, and the whole balance of the body is changed at once. The position of the feet and the balance of the body are the essentials in deciding whether any particular figure represents the start of a race. Dr. Hauser by paying attention to superficial points is led little by little away from the original position till he

51 B.M. Vases E. 6.

${ }^{52}$ Cf. Zannoni. Scavi di Bologna. Taf. xxii. where the central figure is clearly talking to the
Paidotribes, and the supposed resemblance of the attitude to the Vatican Running Girl is utterly worthless. 
ends by confounding together types that are absolutely contradictory. To verify this, one has only to put oneself into the various attitudes and try the effect of a few starts in each attitude.

Setting aside these vases which clearly represent other types let us consider how far the general attitude represented by the Tübingen bronze is consistent with our interpretation of it, as a runner starting. Several objections have been raised. Dr. Hauser hesitated long before adopting this view on account of the 'starke Kniebeugung.' Indeed in his first article he concluded that the movement shown was not that of the start, but that of the restart after the turn in the diaulos, a view which he only abandoned from the false analogy of a figure representing a Lampadedromos, which I propose to discuss later. M. A. de Ridder repeats the objection in far more emphatic language ' On conçoit qu'il n'est pas de condition moins favorable, ni de plus contradictoire au départ.' And he proceeds to explain the whole series as representing athletes preparing to jump!

I confess I utterly fail to see the force of the objection. A visit to a modern race meeting, or reference to pictures representing a start, such as the one shown in the Badminton volume on Athletics, would surely convince Dr. Hauser and M. A. de Ridder that both knees are always more _or, less bent at the start: when the feet are only a few inches apart, there can be but little difference in the bend of the knees, and in those vases where the heel of the hind foot is raised off the ground there is a corresponding difference in the bend of the knees. It is true that the difference is often more marked in a modern runner, but then the feet are much farther apart. Whereas, with the position of the feet as determined by the starting lines, I cannot conceive any position of the knees as possible other than that which we are considering. It is precisely the bend of the knees which may be seen any day on the cricket or football field, the position of one standing ready, on the alert to field the ball, or tackle an opponent. Surely M. de Ridder would not have either or both knees straight!

Further the position of the body and the hands agrees with that of the feet and knees. Just as in modern times, the precise angle of inclination of the body is largely a matter of individual taste, and there is a natural tendency to balance the body by stretching one or both hands to the front. With a shield on the left arm, the right arm is naturally extended in front. In the unarmed race, if the body is much bent, the arm corresponding to the front leg must be well advanced, and the other arm kept back. If the body is nearly upright, both arms may be brought to the front. In any case the arms must be used to balance the body; but the position of the feet does not admit the free use of the arms which we used to see before the present method of starting off the hands was introduced. For we must never lose sight of the fact that we are not considering whether such and such a position is the best according to our modern ideas, but whether it is appropriate to the conditions of a Greek start, i.e., with the feet close together. That the position of the Tubingen bronze is appropriate $\mathrm{I}$ have tried to show.

Again, if it does not represent a runner about to start, what does it 
represent? M. A. de Ridder says a jumper preparing to jump. But a jump must be taken off both feet or off one. In the first case the feet must be absolutely parallel, in the second case the feet are well apart. Both positions are illustrated in the vases which Dr. Hauser has wrongly brought forward as parallels to his Hoplitodromos, and which M. de Ridder rightly interprets as depicting the jump. But the position with one foot a few inches behind the other is appropriate neither to a jump off both feet, nor to a jump off one foot.

M. de Ridder, however, brings forward a most curious argument to prove his view. There is nothing to show, he says, that the scenes depicted refer to the stadium at all, and not rather to the Palaestra. The pillars may. mark the Palaestra as well as the stadium, the draped figure with the rod may be a Paidotribes just as well as a Brabeus or Agonothetes. This is quite true, but not so his next statement. 'Tout exercice en vue d'un jeu est nécessairement différent du jeu même.' M. de Ridder obligingly shows us the particular from which he has arrived at this extraordinary generalisation. Pausanias ${ }^{53}$ describes the votive offering of Epicharinus as a Hoplitodromos 'practising for the armed race.' How did Pausanias know that he was practising instcad of racing? Because the practice was necessarily different from the actual race. What then was the practice for the armed race? The characteristic of the Hoplitodromos, says M. de Ridder, was that he advanced by a series of leaps and bounds. What practice conld be more useful for such a style than jumping? Therefore the Hoplitodromos was represented in the statue as jumping! This too is the meaning of the Tübingen bronze, and of all similar vase paintings $!^{54}$ M. A. de Ridder completes the 'reductio ad absurdum' of his own theory when he solemnly ascribes a similar method of practice to the Lampadedromos!

The description of the style of running is as I have shown appropriate to the Stadiodromos rather than to the Hoplitodromos; but the radical fallacy of the whole argument lies in the words I have quoted. The principal training for any atbletic event does not differ in kind from the event itself. However useful other exercises may be for producing fitness, the diskos thrower must practise the diskos, the jumper jumping, the sculler sculling, the cricketer cricket. No amount of physical training will make up for this special training. So it is with running. The runner may keep himself in training by other forms of exercise, but the most important part of his training is on the running path. It is true he does not in practice habitually run the same distance as in the actual race. But the style of running is the same in practice as in the race, and if he is a sprinter he must especially practise starting. The Greek must have practised not only starting but turning, and this practice must have taken place as far as possible under the same conditions as in the actual race. Accordingly we find

\$3 I. 23.9 .

54 So Reinach describes the Hoplite on an amphora mentioned above as 'Athlète armé en hoplite, sur le point de sauter en présence d'un arbitre des jeux.' Répertoire des Vasos peints, i. 494. 
at Olympia remains of starting lines in the gymnasium precisely similar to those in the stadium. Therefore in studying athletic scenes on the vases it makes no difference whether the painting represents the practice or the competition, the gymnasium or the stadium. The start and the turn must have been the same in practice as in competition. These being the most important parts of practice it would be strange indeed if we did not find them represented among the hundreds of vases which picture Greek athletics. But if the vases which I have described and the Tubingen bronze do not represent the start, where is it represented? The argument from omission becomes still stronger when we remember that the Greek artist does not as a rule depict moments of violent action but prefers moments which mark the beginning or conclusion of action. In the diskos, the spear, the jump, in wrestling, and in boxing we have numerous representations of the preparations for each event, and of the moment before: it would be extraordinary therefore if in running alone this moment were omitted.

\section{C.-Vases representing the Turn in the Diaulos.}

Assuming that we have recognised the position of the start, let us try to interpret the Berlin kylix (Fig. 6), which I bave mentioned, setting beside it two other vases, a kylix formerly at Berlin, of which a drawing is preserved in that Museum (Mappe xxi Taf. 82), and a kylix of Euphronius figured by Hartwig, Meisterschalen, Pl. xvi. In all three the runners run in opposite directions and it is therefore agreed that they represent a diaulos, and the turn in the diaulos. In all three the principal movement is from right to left, and the turu is made to the left. In two of the three an official is standing by with his forked rod ready to see fair play. In all three the turn is represented by the pair of runners to the left. It is on this point that I join issue with Dr. Hauser and M. de Ridder, who both maintain that in the Berlin kylix the two runners to the right represent the turn. For convenience I will keep the numbers which Dr. Hauser has given to these three figures. Dr. Hauser's theory absolutely ignores the attitude of the runner on the extreme left (No. 4), who is leaning forward with his right leg bent, while his head and body and right arm are all turned to the left. According to Dr. Hauser he has already turned and is well on his way back. If so, why is his body turned to the left? He cannot be merely looking back, a position which is represented on the other side of this very kylix, for his whole body is turned and the right arm swung across the body; an action which certainly justifies Dr. Hauser in saying that No. 5 will soon pick him up.

The only possible explanation of this remarkable attitude is that the runner is in the act of turning. He has checked his speed as he nears the post, and then in order to turn with the least possible loss of ground he advances his right foot just in front of the post and throws his weight forward, at the same time turning his whole body to the left. The next moment he will bring up his left foot to a level with the right and turning 
on the left foot start back again with short steps, and throwing his body forward, the right arm still to the front steadying the shield. This is the attitude of No. 6, who cannot possibly be checking his pace before the turn as Dr. Hauser suggests. This explanation leaves us free to class No. 5 with the figures whom we have already recognised as starters. The position of the feet could not possibly occur after the start they are far too close

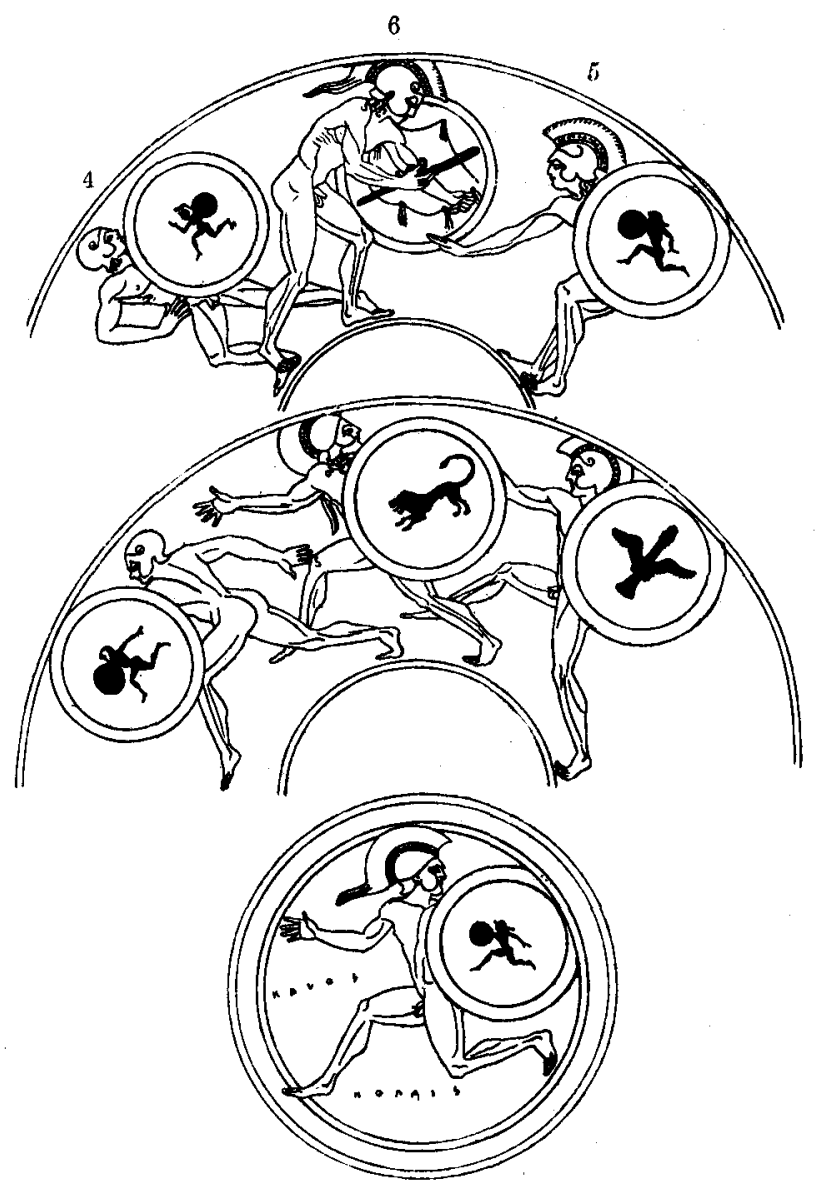

Fig. 6.-R. F, Kiylux, Berujn.

together to represent even the short steps of a runner starting again after the turn. This explanation of the three figures is confirmed when we compare the group to the left with the similar group on the Euphronius kylix (Fig. 7). Here the relative positions of the two runners show that the figure turning round with an anxious look towards the official has not quite reached the turning point, though the position of the body and the shortened stride indicate that he is already thinking of the turn. The figure to the left who 
lias already turned is in exactly the same attitude as No. 6 on the Berlin kylix. The drawing of our third vase preserved in the Berlin Museum (Fig. 8) shows

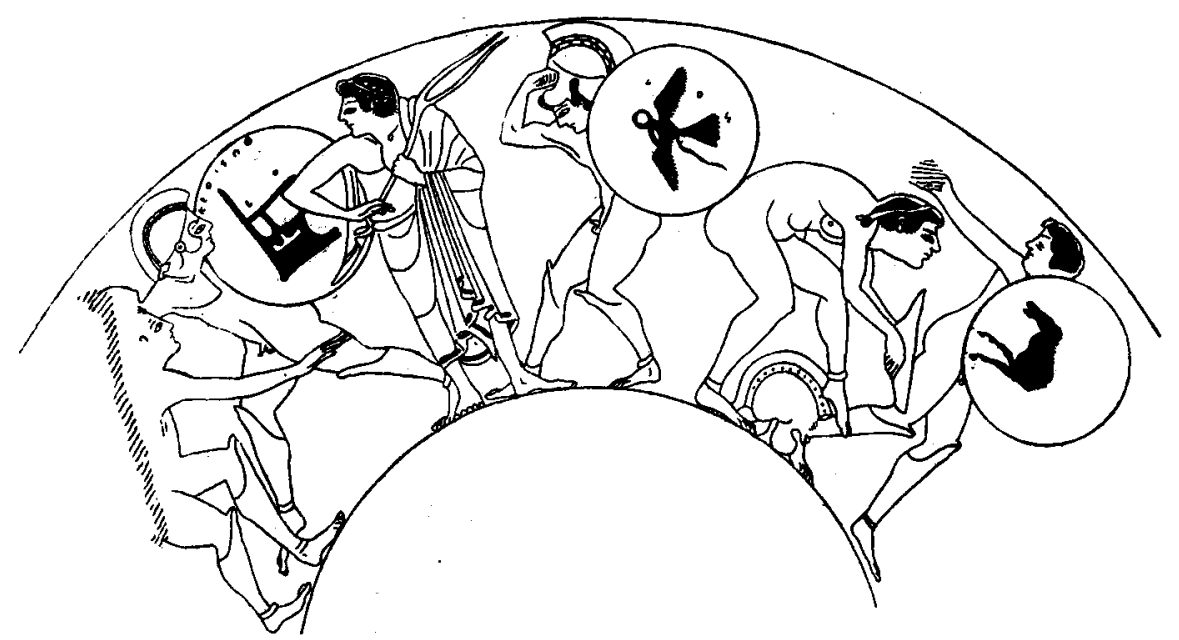

Fir. 7.-R. F. Euphronius Kylix, Paris. (After Hartwig.)
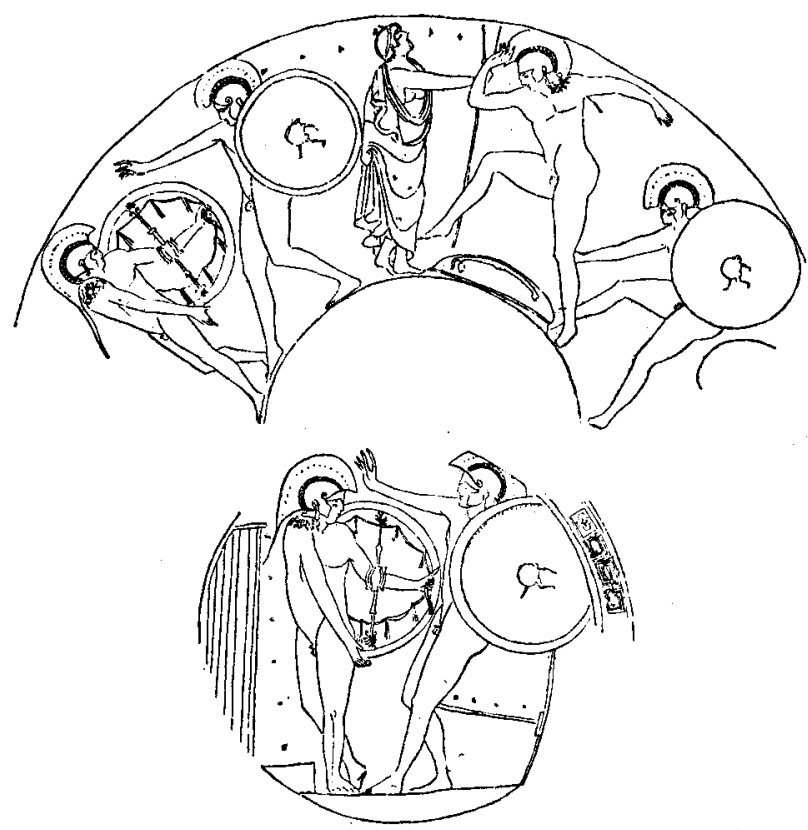

Fig. 8.-R. F. Kylix, formeriy in Berlin.

the turn still more clearly both in the interior and on the exterior. In both cases we see a runner checking himself before the turn by throwing the 
body back, and stretching his right arm to the front. This action is more strongly marked in the figure on the exterior, but in opposition to Dr. Hauser I believe that the moment represented on the exterior is earlier than that shown on the interior. The difference is of little importance, but the more violent check seems likely to precede the less violent attitude where the runner is recovering his balance and is shortening his step. The second figure in each case shows the actual turn, but again the turn is a trifle more advanced on the interior than on the exterior. I have endeavoured to arrange the positions shown on these vases so as to give a complete picture of the turn (Fig. 9). It is remarkable how accurately they follow one another. Six stages are marked:

1. The body is thrown violently back to check the pace. ${ }^{55}$

2. A shorter step follows, the body still thrown back but not so violently.

3. The right. leg is advanced level with the turning point, the body being thrown forward and at the same time turned to the left.

4. The left leg is brought up level with or slightly in front of the right, the body being thereby brought to the upright and continuing to turn.

5 . The turn is completed on the left leg, the right hand grasping the edge of the shield to steady it.

6 . Throwing the body forward the runner starts on the return journey with short steps.

Of course I do not wish to assert that these positions always followed one another in this order, but the mere fact that it is possible so to arrange them, shows the accuracy with which the vase painters observed the various positions at the turn.

It remains to consider the other figures on our vases.

In the Berlin kylix we have seen that both the start and the turn are represented. On the other side three men are running at full speed to the left. In the interior a single figure runs at full speed to the left looking backwards as if with an air of triumph. Does he represent the victor? The same

55 Cf. B. M. E. 78 (Figr. 13 below),

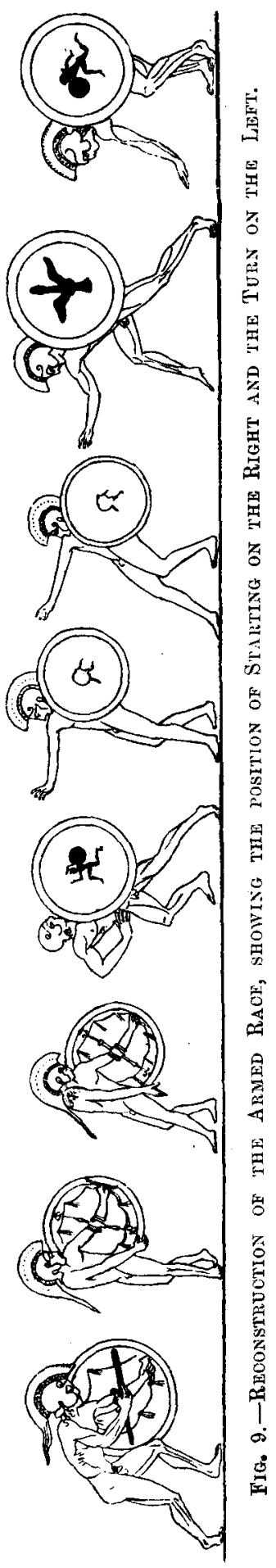


type occurs in the centre of a B.M. kylix E 22,56 and another kylix E. 21 shows an unarmed runner wreathed in the very same position. Such single figures might well represent the victor, and, if so, our kylix depicts every phase of the race from start to finish. ${ }^{57}$

Coming to the Euphronius kylix we find a group of three figures to the right of the Brabeus. The left hand figure of the three may belong to the group on the left, in which case his position is probably the same as No. 1 or 2 in our series. But symmetry seems to suggest that he belongs to the right hand group. The central of the three figures is putting on his greaves, a performance which according to Heliodorus ${ }^{58}$ did take place at the start, while the other two figures are perhaps engaged in a preliminary canter, such as is described by Statius, ${ }^{59}$ in which case the runner with uplifted hand and body bent back is perhaps stopping before turning back. Perhaps this may be the explanation of the right hand group on the lost Berlin kylix, though the context suggests that it really represents the actual race, and that the figure to the left has accidentally dropt his shield. The other runner has evidently just started, his short step and the forward inclination of the body reminding one of the runners who have turned on the Berlin kylix (No. 6), and on the Euphronius kylix.

\section{D.-The Character of the Armed Race.}

These three vases suggest certain points about the armed race. In the first place the turn appears to be made round some point. There is no indication of touching any object, and turning back, or of toeing a line. Moreover the post round which they turned must have been fairly high, otherwise the body would not be thrown forward, as it is, so as to clear the post. Therefore if the runners each ran in his own track, they must have turned round the post to the left, and returned by the other side. But secondly the attitude of the runners halting, with their right hands outstretched, and the way in which they look back at their fellows seem to undicate that they are not running in parallel tracks but all together round some common turning point. As I pointed out, even if the runners in the diaulos ran each round his own goal, it does not follow that the armed runners did the same. The weight and encumbrance of their armour would make the race much slower, and so increase the distances between the runners and lessen any unfairness that might be caused by the start. At the same time there would be considerable danger of fouling (какотє $\chi^{\nu i a}$ ) at the turn, and strict regulations would be necessary to check it. The hoplites who are stopping so suddenly on the lost Berlin kylix seem to be anxious to avoid fouling those in front of them, and thereby disqualifying themselves. Lastly, the less elaborate arrangements, would I believe, be in complete accord with the character of the armed race, a point on which I must say a few words.

${ }_{56}$ Murray, Greck vases in B.M. 18.

57 Similarly a Duris kylix in the B.M. E. 53 shows all the successive stages in boxing.
Cf. Jiithner Antite Turngeräthe, p. 67 .

${ }^{58}$ Acth. iv. $3 \mathrm{f}$,

59 Theb. iv. 587 . 
The armed race belongs to what we may call mixed athletics, that is to say competitious conducted under fancy conditions, such as obstacle races, races in uniform, swimming races in clothes and all the many events which make up a modern Gymkhana meeting. Such events are popular in character: they are not intended for the specially trained athlete any more than a point to point steeplechase is intended for the race horse or the cart horse. Signs are not wanting that the armed race belonged to this class. The entries were apparently large. Twenty-five shields were kept at Olympia for use in the race, though the starting lines only provided separate places for twenty runners. In such races the more competitors the better. Again the armed race was the last event on the programme at Olympia, and elsewhere, and the last event is often of a less serious character than those that have gone before. In modern sports we often end with a sack race, or an obstacle race, and we find the same motive on the Greek stage, where the tragic trilogy was followed by a satyric drama by way of relief. If we had the complete list of the prizes at the Panathenaic games I believe we should find that the Hoplitodromos did not receive so many amphorae as winners in the other events. Unfortunately the inscription ${ }^{60}$ is here wanting, but some confirmation of my point is provided by the parallel of the chariot race. The winner of the chariot race proper received 140 amphorae, the second 40 amphorae. In the race for warchariots the winner received 30 amphorae, and the second 6 only. If such a distinction was made between the race horse and the war horse, it is not unlikely that a similar difference existed in the foot races. In assigning this popular character to the armed race, I do not wish in any way to underrate it, nor is such a view at variance with the importance which Plato attached to it on utilitarian grounds. Plato himself condemns the training of the professional athlete, the object of athletics being according to him not to train athletes, but useful soldiers and citizens; and for this very reason he insists on running in armour. Just so with us, the professional runner would despise the obstacle race, as not serious athletics. But the practice of the obstacle race is an important part of the physical training of our soldiers, for the man who can win such a race is more useful in war than the champion sprinter.

Again there is always something incongruous and comic in the sight of a person running fast in inappropriate costume, a gentleman in a top hat and frock coat with an umbrella in his hand, or a soldier in full uniform with his rifle. There must have been something comic in a race of Greek hoplites with shields and high crested helmets, and this comic side is surely alluded to by Aristophanes when as he passes the chorus of birds in review he makes Peisthetaerus exclaim (Aves 291).

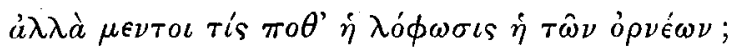

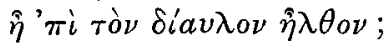

60 C. 1. A, ii. 2, 968.

H.S.-VOL. XXIII. 
Comic incidents must sometimes have occurred, such as the dropping of a shield, an accident which may be depicted on the lost Berlin kylix as I have suggested.

Perhaps this view may help us to explain various vase paintings collected by Dr. Hauser which show runners without their shields, holding their helmets in their hands, putting down or taking up their shields. Dr. Hauser tries to show on this evidence that the armed race was a double diaulos, that the runners on reaching the turning point put down their shields, and ran without them, but took them up again when they reached it the second time. That this was the practice at the greater festivals, there is no proof, and in the absence of direct evidence we must assume that it was not so. At the same time these scenes may well refor to certain forms of running practised in the Gymnasia, or to certain races held at the less important local meetings. Such popular sports naturally lend themselves to variations. The Greeks were fond of acrobatic and gymnastic tricks, and spending as they did so much of their time in athletics we may be sure that they varied the seriousness of pure athletics with lighter competitions of the Gymkhana type.

We have direct evidence that there were such variations in the armed

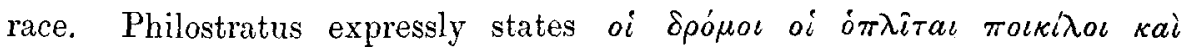

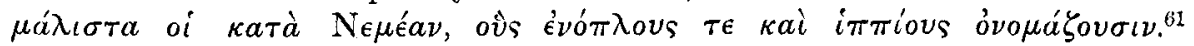
After discussing the traditional origin of the armed race at Olympia, he adds that the best of all the armed races was that at Plataea, first on account of its length, secondly on account of the heavy armour used, which was the same as that in actual warfare, thirdly becanse of its strict regulations, by which anyone who had once won the race, if he entered a second time, was liable to the penalty of death if defeated. From this passage we see that the variety in the race consisted partly in distance, partly in equipment. The ordinary distance appears to have been a diaulos. The

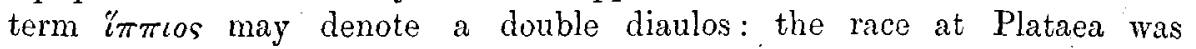
evidently of unusual length. Plato in the Laws suggests an armed race of excessive length, 60 stades for the heavy-armed hoplite, and 100 stades across country for the light-armed bowmen. Here we see that Plato suggests different styles of armament. Philostratus describes the equjp-

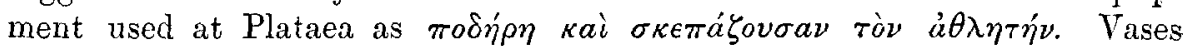
show us that the use of greaves was gradually discontinued. In the earliest vases the usage varies. After 520 B.C. the use of greaves is general. After 450 B.c. it disappears entirely. ${ }^{62}$

But the epithet moı i $\lambda$ os implies more than mere difference in distance or equipment, it implies distinctly the fanciful element of the Gymkhana, and I venture to put forward this idea as a possible explanation of a number of Hoplitodromos vases, otherwise unexplained. It is of course impossible to obtain any certainty as to the details; it will be sufficient if we can thus give a general explanation of certain of these scenes. 
Let me first take the skyphos from the Bourguignon collection which I have already referred to, on which Dr. Hauser thought he saw a trace of the $\ddot{\boldsymbol{v}} \sigma \pi \lambda \eta \xi$. We see a hoplite with a shield on his left arm, stretching forward and supporting himself on his right arm, his feet being close to a
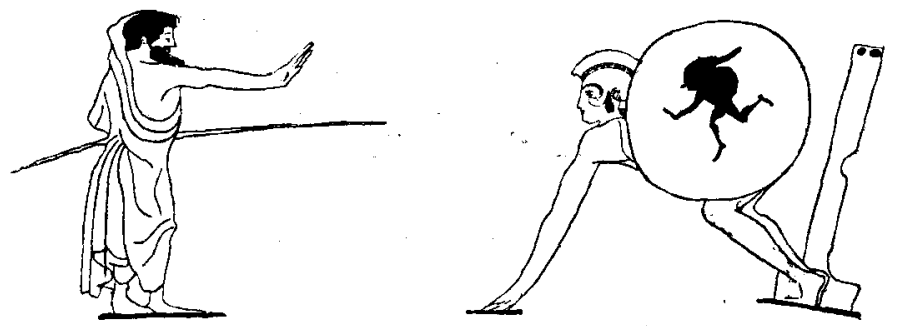

Fic. 10.-Bourguignon Skyrhos. (After. Hauser.)

pillar. On the other side of the vase, but probably connected with the same scene, is a bearded official wearing a himation and carrying a long rod, with his right arm outstretched in a gesture of command. Dr. Hauser describes this hoplite's position as a 'wahres Kunststick von Balance,' and suggests that it represents the position of starting, the object of so unnatural a position being to prevent any competitor from poaching at the start. M. de Ridder rightly sees the absurdity of supposing that the Greeks started in so impossible a position, and he finds in it merely a gymnastic exercise of 'assouplissement,' and compares it with the lost Naples vase already mentioned ${ }^{63}$ which undoubtedly represents a start. The position is a familiar one in gymnastic drill at the present day, known as 'the front leaning rest on the right arm', and is certainly not such a marvel of balance as Dr. Hauser supposes. But $I$ have been unable to find any vase painting of which we can be certain that it represents any form of gymnastic drill. I doubt whether the Greeks of this period practised 'exercices d'assouplissement.' Physical drill is for those who lead a sedentary life in cities, not for those who lead an active life in the open air like the Greeks. Dr. Hauser's explanation seems nearer to the truth. For though it is impnssible to regard this position with him, as a recognised position for the start in serious athletics, such a fanciful position may well have occurred in a race of the less serious type at less important meetings, or in the matches that must have been constantly arranged among the youths in the various Palaestrae. For example in the present day the runners in an obstacle race are sometimes made to lie down for the start.

Another vase where the fanciful element is yet more obvious is a Munich kylix (Fig. 11, Jahn 803). The sponges and implements hanging on the wall show us that the scene belongs to the Palaestra. There are five figures. Two fully armed Hoplites run to the left, carrying their shields in both 
hands in front of them, certainly a most difficult position for runuing. The figure to the left is leaning back, in a position similar to that which we have already seen, apparently to check his pace. Three other athletes run to the right. The runner in the centre is entirely unarmed; perhaps he is merely a Stadiodromos practising and has nothing to do with the other four. The other two have helmets but no shields. The different directions of the runners clearly indicate some form of the diaulos. The whole group seems to suggest a race where the runners on reaching the turn put down their shields and return without them. Perhaps the unarmed runner repre-

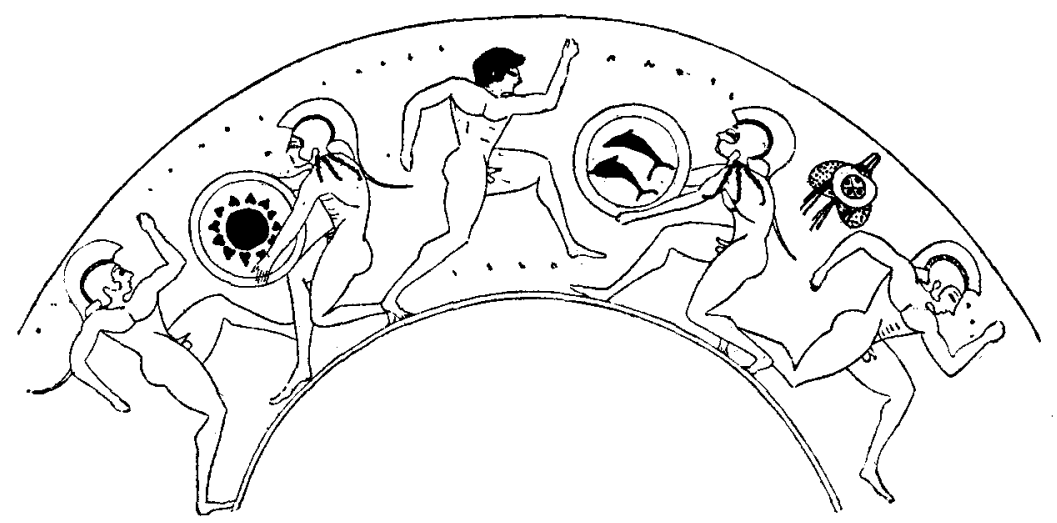

Fig. 11.-R. F, KYLIX, MVxioh.

sents a second lap where they further divest themselves of their helmet. But it is useless to go into details. We can merely recognise in this scene one of the varieties of the armed race of which Philostratus speaks. The motive of putting down or taking up the shield-it is hard to be certain which it is--is shown on three other vases mentioned by Dr. Hauser, a kylix of Hischylos, (Klein, Meistersign. 98.7), a kylix in the Museo Torlonia at Rome, and a Munich kylix (Jahn 1240). A Lykos kylix published by Hartwig (P]. xii), which shows us a runner striding over a shield which lies on the ground, may possibly belong to this group.

\section{E.-The Finish of the Armed Race.}

There are a number of vases where the runner holds his helmet in his right hand. Dr. Hauser classes this type with the vases I have just discussed, and if he is correct, they afford most valuable confirmation of the theory which I have put forward. This motive occurs, however, too frequently, I fear, to be connected with any particular variety of the hoplite race, or, as M. de Ridder holds, to represent merely a practice for the race; and it is therefore better if possible to connect it with the regular type of hoplite race. It occurs on the following vases : 
1. B.M. E 818. R.F. kylix (Fig. 12).

To the right is a fluted pillar, against which lies a shield, apparently belonging to a runner who is just passing the pillar. $\mathrm{He}$ lifts his right hand towards his head, a movement which we have already found on the Euphronius kylix and the lost Berlin kylix, and which occurs on the Lykos

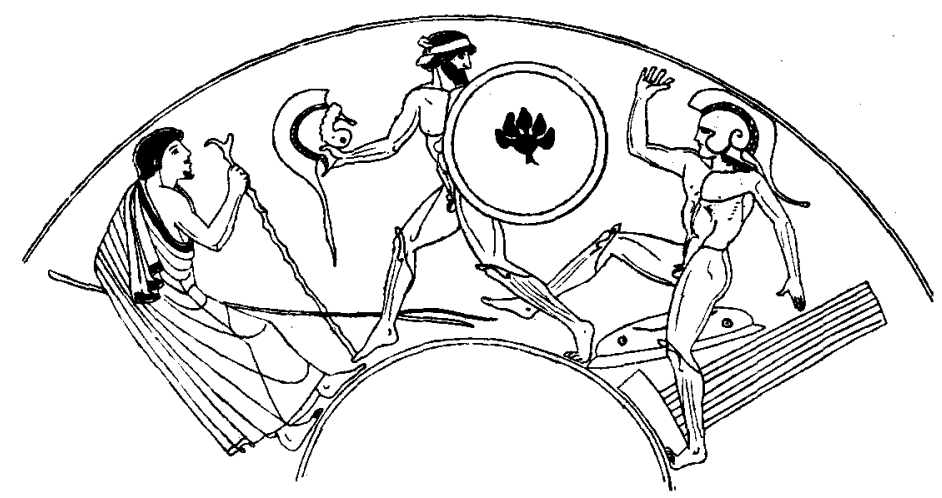

Fig. 12.-R. F. KyLIX IN B.M.

kylix mentioned above. Further to the left another runner looks back on him with a look of triumph holding his helmet in his right hand. The position of the head occurs in the centre of the Berlin kylix, where we suggested that possibly the victor was depicted. Further to the left is an official resting on a staff and holding a forked rod.

2. Pelike. Vienna. (Arch. Anz. 1892, pp. 172 and 198).

To the right a pillar. Beyond it a runner holding his helmet in his right hand, and shield on left arm, strides to the left towards an official with the usual forked rod. On the ground lies a shield with a helmet on the top.

3. B.M. E 78. R.F. kylix (Fig, 13).

A Palaestra scene, in which the only figure who concerns us is a

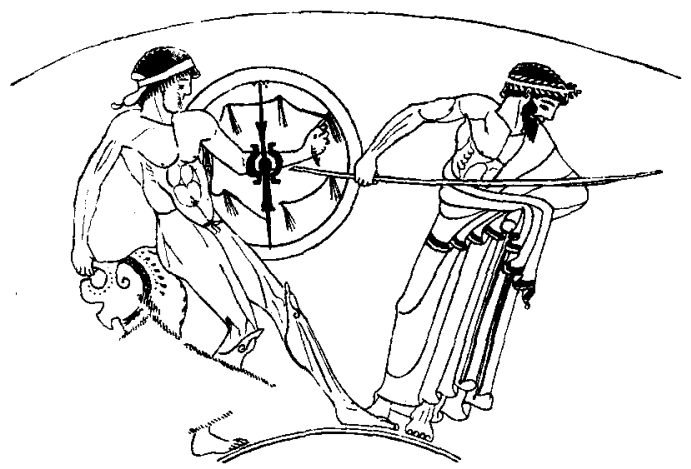

Fig. 13.-R. F. KyLIX IN B.M. 
Hoplitodromos to the right. He is leaning backward in the attitude of the runners stopping before the turn on the lost Berlin kylix. His right knee is bent, his left leg straight, and he holds his helmet in his right-hand behind the body. The attitude is frequent with jumpers and diskoboloi, and is the natural attitude of a runner who suddenly stops, not, as stated in the catalogue, of a runner about to start.

4. Kylix. Mus. Gregor. lxxi. 46. a pillar.

A Hoplitodromos with helmet in right hand behind the body approaches

5. Amphora. Palermo, 2120 (Jahrb. 1895, p. 198).

A Hoplitodromos moving to the right looks back at an official of the usual type and holds his helmet in his right hand level with his head.

6. Amphora. Naples, Heydemann, 3083.

Almost idenlical with No. 5 .

7. Kylix. Berlin, 4039, Coll. Sabouroff I 53.

A runner in a somewhat stooping attitude runs to the right apparently about to put down his shield, the rim of which seems to touch his left foot. He holds his helmet in right hand behind the body.

8. Fitzwilliam Museum, Cambridge, R.F. kylix, Harțig, Meisterschalen, Fig. 14, not mentioned by Hauser (Fig. 14).

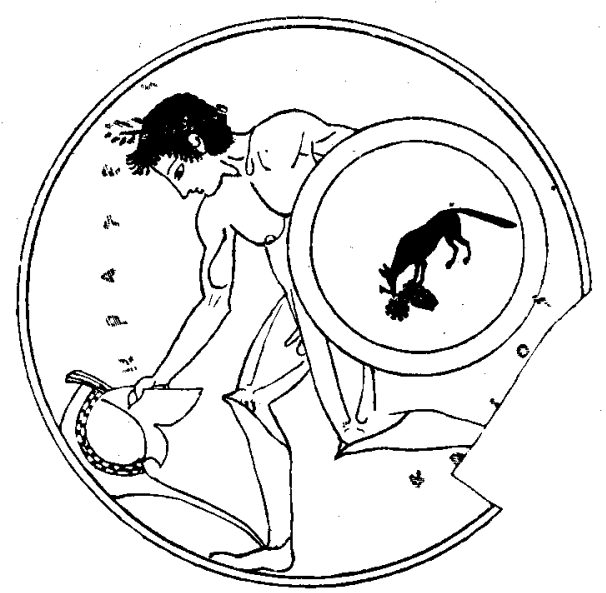

Fig. 14.-R. F. Kylix, Cambridge.

A runner in a somewhat stooping attitude, his shield held low on left arm, helmet in right hand in front of body. On his head he wears a wreath.

To these we may perhaps add 
9. An amphora from the Bourguignon collection. (Jahrb. 1895, p. 199, Fig. 34).

The runner moves towards an official who makes a gesture as if to stop him. He lifts his right hand to his helmet as if about to take it off.

This same gesture occurs on

10. Lykos Kylix (Hartwig. pl. lxii. 1).

The runner's shield lies on the ground, and his right hand almost touches his helmet. The whole attitude is almost identical with that of the right hand runner in No. 1. In both cases it seems as if he has thrown his shield down and is about to take off his helmet; in this kylix he is evidently checking his pace. In the field are a strigil and aryballos.

If these scenes do not belong to some variety of the hoplite race, or to practice merely, but to the regular race, what do they represent? The solution is to be found, I think, in the first of the series. In this vase as in Nos. 2, 4, we find a pillar. This pillar must represent one end of the course, either the start, or the turn, or the finish. We have seen similar pillars at the start, and at the turn, and we have recognised certain positions as belonging either to the start, or to the turn, to which these do not correspond. The inference is that here we have the finish of the race, or the moment just after the finish, and further examination confirms this view, In no case are the runners going at full pace, in most cases they are clearly checking their pace, in No. 3 the check is most marked. In Nos. 1, 2, 5, 6, 9, we see an official, probably the Brabeus with his forked rod, whom we have also seen at the start and at the turn. In Nos. 1, 2, the runner has just passed the post, in No. 4 he is just reaching it. In No. 1 we see two runners, the first, as Mr. Cecil Smith says, wins easily, the second seems not to have dropt his shield but thrown it down, perhaps in disgust. In No. 2 a second runner, perhaps the winner; is suggested by the shield and helmet on the ground. In neither of these vases is the attitude appropriate either to the start or to the turn, while all the details point to the finish. Finally what could be more natural than at the close of a 400 yards race in armour under a scorching sun to take off the cumbrous, heavy helmet! Perhaps too it may have been a point of etiquette for the winner to do so, just as a cricketer returning to the pavilion after a fine innings takes off his cap. And so the attitude may be symbolical of victory, and the single figures which we see in Nos. 7 and 8 may represent the victor, and the wreath around the hoplite's head may be the wreath of victory. To determine the motive of a single figure is difficult, but surely nothing could be more natural than to represent a runner as a victor, by introducing some gesture typical of victory, either the helmet in the right hand, or the back-turned head, as I suggested in the centre figure of the Berlin kylix, or both as in the first vase of this series. The Lykos kylix presents greater difficulties. Has he dropped his shield, as in the lost Berlin kylix, or is he defeated as in the vase just mentioned, or does he belong to the previous 
group of runners who put down their shields at the turn? The attitude must have been a familiar one in the palaestra, and perhaps the strigil and aryballos in the field indicate that this is merely a palaestra scene.

\section{F.-Arming for the Race, and other scenes.}

If my explanation of this group is correct, our series is now complete. We have seen the start, the actual race, the turn: now we have the finish. To these we may add vases which show athletes arming before the race. This scene occurs on the Euphronius kylix already described, and also on a kylix in the British Museum (E 22). The youth in the centre is bending down to

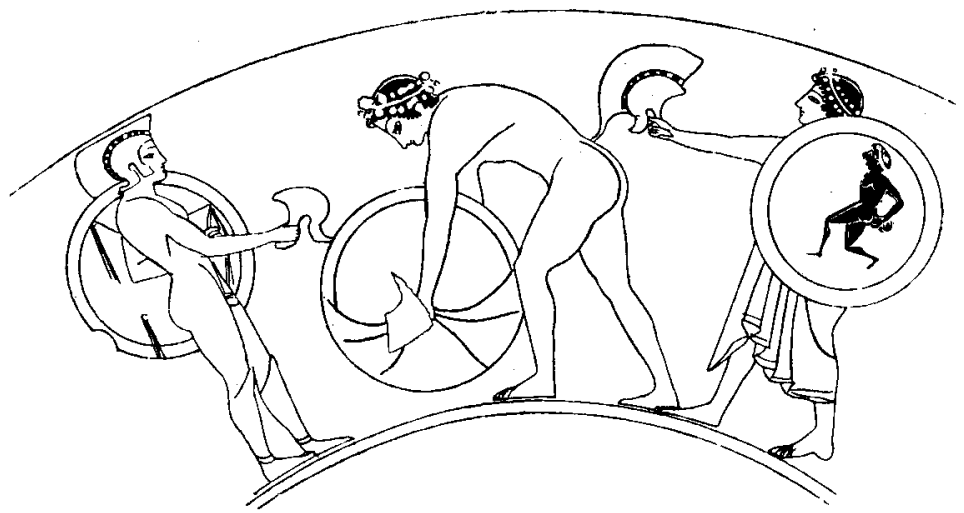

FIG. 15.-R. F. KYLIX IN B.M. E. 22 .

take his shield from its $\sigma a ́ r \mu a$. On the other side we see four hoplites running in very precise and regular order and holding spears in their right hand as if about to throw them. It has been suggested that they represent a a variety of the armed race in which the runners carried spears, and a similar explanation has been given of a vase figured by Gerhard (A.V. 258.4). This seems hardly probable. Apart from the danger of running with spears, especially in a race involving a turn, the regularity of the runners is much more appropriate to some purely military exercise, such as a charge, and this view is confirmed when we compare them with Gerhard $A . V .258 .1$, which can only represent a charge. There is moreover no literary evidence for such a race. The combination of a purely military exercise with preparations for the armed race suggests that the latter, as we might have expected, formed a regular part of the hoplite's training.

Since the above was written another most interesting kylix belonging to Sir Frederick Cook has been exhibited at the recent exhibition of the Burlington Fine Arts Club (Pt. III. 17). I much regret that I am unable to reproduce it; it is to be hoped that it will soon be published. The interior represents a robed official, standing between a low seat and a fluted pillar, the exterior two 
groups of Hoplitodromoi. On the one side are two youths running to the left, holding their helmets in their right hands in front of them. They are checking their pace, with the right leg advanced and straight and the body leaning back. Between them is a robed official holding a forked staff. To the right is a skapane. On the other side, we see a fluted pillar to the right, and another runner in the same position as the first pair running to the left. Beyond him is another official as on the other side, looking towards an unarmed youth who stands with both hands extended to the front, the right, foot a few inches in front of the left, and the knees slightly bent. His position is identical with that of the runner figured by Hartwig (fig. 6) which I have already described in connection with the start. On the ground beside him lies his shield with his helmet upon it.

This interesting vase has many analogies with those already described, but has also some special difficulties. The skapane apparently indicates that the scene is in the Palaestra. As in the Munich kylix one of the runners has taken off his shield and helmet. He is apparently practising starts unarmed. The other three all hold their helmets in their hands. The one by the pillar might well represent the finish, as in the vases already discussed, but what of the other two? Perhaps they are practising without their helmets for comfort, or perhaps the artist has taken a typical position in the race which pleased him, and repeated it for the sake of symmetry. Such symmetrical arrangements are very common in athletic vases, and this vase is essentially symmetrical. We must not forget that the vase-painter's object is not to illustrate a treatise on Greek sports but to produce a pleasing picture, and that considerations of space and composition are more important for him than the literal representation of actual arrangements. Hence vases, invaluable as they are for the style and positions of Greek athletes, are not always safe guides for the actual arrangernents of the sports.

In the preceding discussion I am conscious how much I have left vague and uncertain. Vases often suggest rather than prove, and it. seems safer to try to interpret their suggestions generally rather than to explain dogmatically every detail without sufficient evidence. It will be sufficient if $I$ have shown the various movements of the armed race represented on the vases and certain general characteristics of the race.

\section{G.-Whe lighter side of the Greek Athletics.}

In the view which $I$ have taken of the character of the armed race I have assumed that the comic element would enter into Greek sports; we may go further, there were certain races which were essentially comic, such as the Lampadedromia, and the Oschophoria. The Lampadedromia was of course a religious or festival race, originally connected with the worship of the fire-god. But the history of Greek comedy sufficiently proves that the comic element was not excluded from Greek religion, and Aristophanes is our witness to the comic character of the torch race. It is a pastime essentially 
for the young, and Bdelycleon mentions it together with hunting the hare and the boar ( $V e s p .1203$ ) as types of the youthful exploits of which his father should boast

\author{
$\dot{a} \lambda \lambda \dot{\omega} s \grave{\eta} \kappa a ́ \pi \rho o \nu$

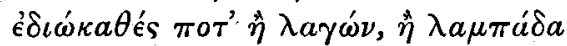

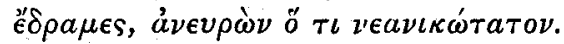

The stooping attitude adopted by the runners in their efforts to keep the torch alight was proverbial.

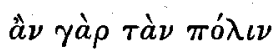

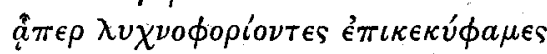

says the herald describing the sorry plight of the men in the Lysistrota (1002); and again in the Frogs Aeschylus says of the degenerate youth of the day (Ran. 1087)

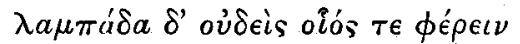

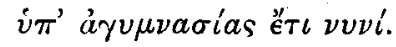

And Dionysus tells how he nearly died of laughter at the slow clumsy efforts of some fat, white-fleshed youth toiling along in the rear, bent double ( $\kappa$ ú $\psi$ as), while the potters at the gates speed him on his way with slaps on various portions of his person.

It is just this stooping attitude which is depicted on a small kylix published by Dr. Hauser. The drawing is poor and much broken, but it shows us clearly a torch runner standing near a pillar, his feet close together, his knees much bent, stooping forward with the torch in his left hand, a picture of comical anxiety, such as is familiar to all who have seen an egg and spoon race. Is he standing ready to start, as Dr. Hanser says? It seems very likely. In a drawing so much damaged, we cannot say what the pillar represents, it may represent an altar, or it may represent the pillar at the start of the race. But whether our torch runner is about to start, or not, and personally I am inclined to think he is, his attitude has no conuection whatsoever with that of the starter in the armed race, or in the stadium. And yet it is the evidence of this figure which convinces Dr. Hauser that the Tübingen bronze represents the start, and not, as he first said, the restart after the turn. For the torch race, he says, was no diaulos, and there was no turn. But if Dr. Hauser treats this vase too seriously, M. de Ridder is far more to blame, for he calls attention himself to the passage in the Frogs to which I have referred. $\mathrm{He}$ interprets both vase-painter and poet with the same want of humour. We are not dealing, he says, with a real race, because the torch race started from an altar, and in the vase we see a pillar. The pillar, he says, denotes the palaestra where the torch runners practised, and then he quotes the above lines of Aristophanes to show how severe must have been the training for the torch race. How then, he asks, did the torch runner practise? Surely by jumping, which must have been as efficacious for the torch runner as for the Hoplitodromos. And so the explanation of the vase painting is obvious, the torch runner is practising jumping. This is a 
fair statement of M. de Ridder's argument, set forth on pages 231 and 232 of the Bulletin for 1897. One can only regret that a writer of such learning should have given his authority to a theory, the fallacies of which must be obvious to anyone who has any practical knowledge of athletics, or who car enter at all into the spirit of Aristophanes.

Another race, where the festal element was yet more strongly marked, was the Oschophoria connected with the worship of Dionysus. Certain youths dressed in women's clothes ran bearing branches of grapes from the temple of Dionysus to that of Athena Skiras, the winner receiving as his prize a drink made of wine, honey, cheese, flour, and oil. A somewhat similar ceremony called Staphyledromia took place at the Spartan Karneia.

This lighter side of Greek sports might be further illustrated from the vase paintings, especially from those which represent the sports of boys. To take a single example, we often see boys with hoops; sometimes they are being crowned ; on a Vienna krater ${ }^{64}$ we see a youth with a hoop receiving a a prize. These vases clearly suggest some form of hoop race. Caricatures of athletic subjects are not infrequent. A kylix exhibited at the Burlington Fine Arts Club ${ }^{65}$ shows an excellent caricature of the chariot race. Other vases depict a variety of acrobatic performances. Such scenes help to remind us how fragmentary is our knowledge of Greek sports and games, and teach us that if athletics were a serious business with the Greeks they had also a lighter side which must not be forgotten. Greek life was full of humour, and without a sense of humour it cannot be understood.

In conclusion I must express my indebtedness to Dr. Hauser for kindly allowing me to reproduce several of the vase paintings which he has published. If $I$ have ventured to differ from him in certain details, I freely acknowledge that his careful researches have laid the foundation of our knowledge of the armed race. My thanks are also due to Mr. A. S. Murray for permission to reproduce certain vases from the British Museum, and also to Mr. H. B. Walters of the British Museum for the constant assistance and advice which I have received from him.

E. Norman Gardiner. 